\title{
PENGARUH PERSEPSI KEBERMANFAATAN, PERSEPSI KEMUDAHAN, DAN PERSEPSI EFISIEN WAJIB PAJAK ORANG PRIBADI PADA PENGGUNAAN E-FILING
}

\section{Gede Mahaputra Chrisandita, I Made Sukartha}

Universitas Udayana (UNUD) Bali, Indonesia

Email:mhpchr@gmail.com, made.sukartha@gmail.com

\begin{abstract}
Abstrak
Perkembangan dalam bidang teknologi dan informasi terjadi dengan cepat di era globalisasi sekarang dengan adanya perkembangan ini, beberapa bidang di Indonesia mengalami kemajuan. Tujuan penelitian ini adalah untuk mengetahui pengaruh persepsi kebermanfaatan, persepsi kemudahan, dan persepsi efisien wajib pajak orang pribadi pada penggunaan $e$-filing. Belum semua wajib pajak menggunakan $e$ filing dikarenakan banyak wajib pajak yang belum paham serta masih minimnya kemampuan wajib pajak tentang pengoperasian e-filing. Penelitian berlokasi di Kantor Pelayanan Pajak (KPP) Pratama Denpasar Timur, teknik penentuan sampel yang digunakan adalah nonprobability sampling yaitu incidental sampling. Jumlah sampel adalah 100 responden. Metode penelitian ini menggunakan kuesioner sebagai pengumpulan data dan analisis regresi linear berganda digunakan sebagai teknik analisis. Berdasarkan hasil uji variabel menunjukkan bahwa persepsi kebermanfaatan, persepsi kemudahan, dan persepsi efisien berpengaruh positif pada penggunaan $e$ filing, artinya semakin wajib pajak orang pribadi mempersepsikan $e$-filing dapat meningkatkan manfaat, peningkatan kemudahan, dan peningkatan efisiensi maka penggunaan $e$-filing oleh wajib pajak orang pribadi akan meningkat.
\end{abstract}

Kata Kunci: persepsi kebermanfaatan; persepsi kemudahan; persepsi efisien; penggunaan $e$-filing; wajib pajak orang pribadi

\section{Abstract}

Developments in the field of technology, as well as information with rapid occurrence in the current era of globalization, as well as with this development several fields in Indonesia development. The purposes of this study are to determine the effect of perceived usefulness, perceived ease of use, and perceived efficient of individual taxpayers on using e-filing. Not all taxpayers use e-filing because many taxpayers do not understand and the ability of taxpayers to operate e-filing is still lacking. The research is located at the East Denpasar Pratama Tax Office, the sampling technique used is nonprobabilitity sampling, namely incidental sampling. Total samples are 100 respondents. This study used questionnaires as a data collection method and multiple linear regression analysis is used as an analytical technique. Based on the results of the test variables show that the perceived usefulness, perceived ease of use, and perceived efficient have a positive effect on the use of e-filing, meaning that the 
more the Individual Taxpayer perceives e-filing can increase usefulness, increase easiness, and increase efficiency, the used of e-filing by Taxpayers will increase.

Keywords: perceived usefulnes; perceived ease of use; perceived efficient; individual taxpayer

\section{Pendahuluan}

Perkembangan dalam bidang teknologi dan informasi terjadi dengan cepat di era globalisasi, sekarang dengan adanya perkembangan ini beberapa bidang di Indonesia mengalami kemajuan salah satunya adalah dalam bidang pemerintahan. Instruksi Presiden (Inpres) Nomor 6 Tahun 2001 tentang Pengembangan dan Pendayagunaan Telematika di Indonesia menyatakan bahwa seluruh jajaran aparatur pemerintah dan pihak-pihak lain pengguna telematika untuk mendukung good governance dan mempercepat proses demokrasi. Salah satu pemanfaatan yang mendukung e-government pada bidang perpajakan adalah electronic tax filing (e-filing).

Pasal 1 ayat 1 Undang-Undang (UU) Nomor 28 Tahun 2007 mengenai Ketentuan Umum dan Tata Cara Perpajakan yang menyatakan sebagai berikut, pajak adalah kontribusi wajib kepada negara yang terutang oleh orang pribadi atau badan yang bersifat memaksa berdasarkan UU dengan tidak mendapatkan imbalan secara langsung dan digunakan untuk keperluan negara bagi sebesar-besarnya kemakmuran rakyat. Sampai saat ini pemerintah masih memungut pajak yang akan digunakan sebagai sumber penerimaan Negara. Penerimaan terbesar negara setiap tahunnya adalah penerimaan dari sektor pajak. Pemerintah menargetkan penerimaan pajak dalam negeri yaitu sebesar Rp1.618,1 triliun pada APBN 2018. Tabel 1 menunjukkan realisasi penerimaan pajak pada tahun 2018 yaitu sebesar Rp1.521,38 triliun atau 78,33\% dari penerimaan negara, realisasi penerimaan pajak pada tahun 2018 hanya 94,02\% terhadap target APBN 2018.

\section{Tabel 1}

\section{Realisasi APBN dan Penerimaan Pajak Tahun 2016-2018 (dalam Triliunan} Rupiah)

\begin{tabular}{cccc}
\hline Tahun & Penerimaan Pajak & Penerimaan Negara & Persentase \\
\hline 2016 & $1.249,50$ & $1.555,93$ & $80,31 \%$ \\
\hline 2017 & $1.343,53$ & $1.666,38$ & $80,63 \%$ \\
\hline 2018 & $1.521,38$ & $1.942,34$ & $78,33 \%$ \\
\hline
\end{tabular}

Sumber: www.kemenkeu.go.id/apbnkita (diunduh pada tanggal 15 September 2019)

Direktorat Jenderal Pajak (DJP) membuat layanan $e$-filing pada website DJP yang telah terintegrasi dalam layanan DJP Online sehingga lebih efektif serta efisien dalam memaksimalkan penerimaan dari bidang perpajakan. Sistem ini memiliki tujuan untuk menyediakan fasilitas pelaporan SPT secara online kepada pajak, maka dari itu wajib pajak orang pribadi dapat melakukannya dari rumah atau wajib tempatnya bekerja, sedangkan wajib pajak badan dapat dilakukan dari kantor (Lie \& Sadjiarto, 2013).

Wajib pajak mempunyai anggapan bahwa penggunaan sistem komputer dalam pelaporan SPT sangat membuat bingung dan kesulitan dalam penggunaannya (Setyana, 
2017). Penyebabnya adalah masih banyak wajib pajak yang belum paham tentang pengoperasian $e$-filing dan kemampuan wajib pajak dalam menggunakan $e$-filing masih sangat sedikit (Setyana, 2017). Sistem e-filing adalah sistem yang bermanfaat, tetapi wajib pajak belum mengetahui manfaat yang tersedia dari penggunaan e-filing. Hal tersebut dikarenakan sistem tersebut masih tergolong baru (Setyana, 2017). Sampai saat ini fiskus tidak mewajibkan wajib pajak untuk melaporkan SPT melalui $e$-filling dan menyebabkan penggunaan $e$-filling masih bersifat opsional. Penggunaan $e$-filing yang masih bersifat opsional dan tidak adanya paksaan ini menyebabkan masih sedikitnya wajib pajak untuk melaporkan SPT-nya melalui layanan $e$-filing.

Beberapa teori yang memengaruhi penerimaan pada suatu teknologi dilihat dari minat penggunanya. Teori pertama adalah Technology Acceptance Model (TAM). Terdapat dua faktor untuk memprediksi penerimaan pengguna dalam TAM yaitu perceived usefulness (persepsi kebermanfaatan) dan perceived ease of use (persepsi kemudahan) (Syaninditha \& Setiawan, 2017). Persepsi kebermanfaatan adalah suatu keyakinan bahwa pengguna mengantisipasi efisiensi kinerja dapat ditingkatkan oleh sistem aplikasi tertentu, sedangkan persepsi kemudahan penggunaan adalah keyakinan bahwa pengguna berharap untuk tidak mengeluarkan upaya yang besar dalam menggunakan sistem tertentu (Chang, Yan, \& Tseng, 2012). Peneliti berpendapat bahwa persepsi efisien dapat dikaitkan dengan persepsi kebermanfaatan dan persepsi kemudahan dalam penggunaan suatu sistem aplikasi tertentu yang dapat digunakan oleh pengguna dalam meningkatkan kinerja dan serta tidak mengeluarkan upaya yang besar untuk mencapai tujuan. TAM memiliki kaitan dengan $e$-filing, yaitu minat dari pengguna dalam penerimaan penggunaan sistem (e-filing). Teori lainnya adalah Theory of Planned Behavior (TPB), Ajzen dalam (Dharma \& Noviari, 2016) menyatakan TPB menggunakan 3 (Tiga) faktor yaitu behaviour belief (keyakinan perilaku), normative belief (keyakinan normatif), dan control belief (keyakinan pengendalian). Tiga faktor tersebut dapat menimbulkan minat suatu individu untuk menggunakan suatu sistem ( $e$-filing) atau tidak. TPB yang digunakan pada penelitian (Tallaha, Shukor, \& Hassan, 2014), (Gupta, Zaidi, Udo, \& Bagchi, 2015), dan (Aziz, Azuan, \& Bani, 2017) menunjukkan bahwa TPB memengaruhi niat untuk menggunakan sistem $e$-filing.

Persepsi sangat unik, yaitu unik dalam rangsangan apa yang kita deteksi, terutama cara kita untuk memprosesnya (Démuth, 2013). Persepsi antara wajib pajak satu dengan yang lainnya dalam penggunaan e-filing berbeda-beda, maka penting untuk melihat bagaimana persepsi wajib pajak dari segi kebermanfaatan, kemudahan, dan efisiensi dalam penggunaan $e$-filing. Persepsi kebermanfaatan merupakan keyakinan seseorang bahwa dengan penggunaan suatu sistem informasi akan mampu memberikan keuntungan bagi mereka yang nantinya akan dapat meningkatkan kinerjanya (Setyana \& Yushita, 2018). Persepsi kemudahan dapat mengurangi usaha (baik waktu dan tenaga) wajib pajak dalam mempelajari e-filing (Syaninditha \& Setiawan, 2017). Persepsi efisien adalah kepercayaan seseorang bahwa dalam melakukan pekerjaannya akan memperoleh manfaat yang lebih besar dari biaya atau usaha yang telah dikeluarkannya. 
Peraturan Menteri Keuangan Nomor 210/PMK.01/2017 tentang Organisasi dan Tata Kerja Instansi Vertikal Direktorat Jenderal Pajak menyebutkan bahwa KPP Pratama Denpasar Timur merupakan salah satu instansi vertikal. KPP Pratama Denpasar Timur bila dibandingkan dengan KPP Pratama Denpasar Barat, KPP Pratama Badung Selatan, dan KPP Pratama Badung Utara, KPP Pratama Denpasar memiliki jumlah Wajib Pajak Orang Pribadi (WPOP) terbanyak ke-2 dan jumlah WPOP terbanyak ke-1 adalah KPP Pratama Denpasar Barat, namun KPP Pratama Denpasar Barat memiliki tingkat rasio antara realisasi WPOP pengguna $e$-filing dengan sasaran WPOP pengguna $e$-filing yang lebih rendah dari KPP Pratama Denpasar Timur, sehingga KPP Pratama Denpasar Timur digunakan sebagai lokasi penelitian. Tabel 2 menunjukkan jumlah WPOP Terdaftar wajib SPT dan WPOP pengguna $e$-filing tahun 2016-2018 di KPP Pratama Denpasar Timur.

\begin{tabular}{|c|c|c|c|}
\hline \multicolumn{4}{|c|}{$\begin{array}{c}\text { Tabel } 2 \\
\text { Jumlah Wajib Pajak Orang Pribadi (WPOP) Terdaftar Wajib SPT dan WPOP } \\
\text { Pengguna } e \text {-filing di KPP Pratama Denpasar Timur } \\
\text { Tahun 2016-2018 }\end{array}$} \\
\hline Tahun & $\begin{array}{l}\text { WP OP Terdaftar } \\
\text { Wajib SPT }\end{array}$ & Pengguna $e$-filing & Persentase \\
\hline 2016 & 51.662 & 32.795 & $63,48 \%$ \\
\hline 2017 & 52.417 & 34 & \\
\hline 2018 & 40.423 & 24.754 & $61,24 \%$ \\
\hline
\end{tabular}

Sumber: KPP Pratama Denpasar Timur, 2019

Tabel 2 memperlihatkan peningkatan pada WPOP terdaftar wajib SPT dan WPOP pengguna $e$-filing di tahun 2016-2017, namun pada tahun 2018 terjadi penurunan pada WPOP terdaftar wajib SPT dan WPOP pengguna $e$-filing. Banyak WPOP pensiunan yang menjadi WP Non Efektif (NE), sehingga tidak lagi menyampaikan SPT tahunan. Persentase antara WPOP pengguna $e$-filing dengan WPOP terdaftar wajib SPT pada tahun 2016-2018 tetap melebihi 50\% walaupun terjadi penurunan pada WPOP terdaftar wajib SPT dan WPOP pengguna $e$-filing di tahun 2018, artinya WPOP terdaftar wajib SPT lebih banyak menggunakan $e$-filing untuk melaporkan kewajiban perpajakannya dibandingkan dengan melapor SPT secara manual ke KPP Pratama Denpasar Timur.

Beberapa faktor dalam penelitian ini dapat mempengaruhi seseorang dalam menggunakan suatu aplikasi yaitu persepsi kebermanfaatan, persepsi kemudahan, dan persepsi efisien pada penggunaan e-filing. Faktor-faktor tersebut dapat memengaruhi WPOP menggunakan $e$-filing. Beberapa peneliti sebelumnya seperti (Noviandini, 2012), (Lie \& Sadjiarto, 2013), serta (Syaninditha \& Setiawan, 2017) menyatakan bahwa persepsi kebermanfaatan berpengaruh positif terhadap penggunaan e-filing. Persepsi kegunaan sebagai suatu ukuran dimana penggunaan suatu teknologi dipercaya akan mendatangkan manfaat bagi setiap individu yang menggunakannya (Wahyuni, 2015). Jika persepsi kegunaan seorang wajib pajak orang pribadi terhadap sistem e-filing semakin kuat, maka wajib pajak akan bersedia menggunakan fasilitas $e$-filing dalam melaporkan kewajiban perpajakan (Wahyuni, 2015). Dapat disimpulkan bahwa persepsi kebermanfaatan merupakan penentu suatu sistem dapat diterima atau tidak oleh pengguna 
untuk melaporkan kewajiban perpajakannya. Hipotesis pertama dalam penelitian ini berdasarkan uraian diatas adalah. WPOP.

$\mathrm{H}_{1}$ : Persepsi kebermanfaatan berpengaruh positif pada penggunaan $e$-filing bagi

Faktor untuk memprediksi penerimaan pengguna dalam TAM, salah satunya yaitu perceived ease of use (persepsi kemudahan). Persepsi kemudahan merupakan tingkatan dimana seseorang percaya bahwa teknologi informasi mudah untuk dipahami (Syaninditha \& Setiawan, 2017). Beberapa peneliti sebelumnya seperti (Dharma \& Noviari, 2016), (Syaninditha \& Setiawan, 2017), serta (Dewi \& Noviari, 2018) menyatakan bahwa persepsi kemudahan berpengaruh positif terhadap penggunaan $e$ filing. Hipotesis kedua dalam penelitian ini berdasarkan uraian diatas adalah.

$\mathrm{H}_{2}$ : Persepsi kemudahan berpengaruh positif pada penggunaan $e$-filing bagi WPOP.

Persepsi efisien dapat dikaitkan dengan persepsi kebermanfaatan dan persepsi kemudahan dalam penggunaan suatu sistem aplikasi tertentu yang dapat digunakan oleh pengguna dalam meningkatkan kinerja dan serta tidak mengeluarkan upaya yang besar untuk mencapai tujuan. Dapat disimpulkan bahwa efisien merupakan segala upaya yang dapat dilakukan untuk mencapai tujuan dan manfaat yang dirasakan lebih besar dibandingkan dengan jumlah pengorbanan atau sumber daya yang dikeluarkan. Beberapa peneliti sebelumnya menyatakan penerapan e-SPT PPN berpengaruh terhadap efisiensi pengisian SPT menurut persepsi wajib pajak (Lingga, 2012). Penerapan e-SPT PPN berpengaruh terhadap efisiensi pengisian SPT (Tamboto, 2013), dan penerapan $e$-filing berpengaruh positif pada efisiensi pelaporan pajak penghasilan orang pribadi (Febriani \& Andi, 2016). Hipotesis ketiga dalam penelitian ini berdasarkan uraian diatas adalah:

$\mathrm{H}_{3}$ : Persepsi efisien berpengaruh positif pada penggunaan e-filing bagi WPOP. Model penelitian dalam penelitian ini dapat dilihat pada Gambar 1, berikut:

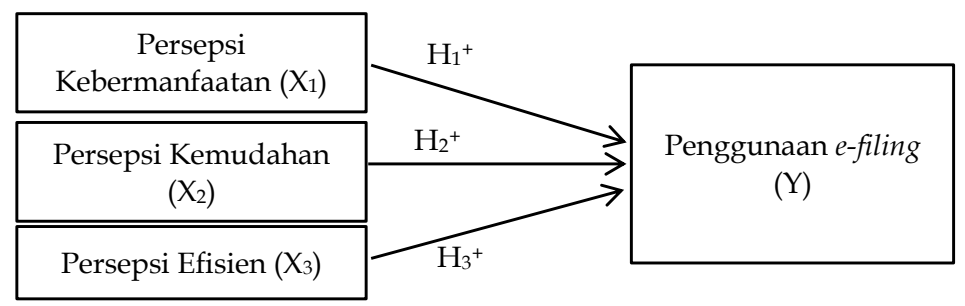

Gambar 1

Model Peneltian

Sumber: Data Penelitian, 2019

Tujuan penelitian ini adalah untuk mengetahui pengaruh persepsi kebermanfaatan, persepsi kemudahan, dan persepsi efisien wajib pajak orang pribadi pada penggunaan $e$ filing. 


\section{Metode Penelitian}

Metode penelitian yang digunakan yaitu analisis regresi linear berganda. Diperlukan pengujian asumsi klasik yang meliputi uji normalitas, uji multikolinearitas, serta uji heteroskedastisitas sebelum melakukan uji regresi linear berganda. Pengujian selanjutnya yaitu uji koefisien determinasi $\left(\mathrm{R}^{2}\right.$ ), uji kelayakan model (uji F), dan uji hipotesis (uji t). Model regresi linier berganda yang digunakan dalam penelitian ini ditunjukkan oleh persamaan sebagai berikut.

$$
\mathrm{Y}=\alpha+\beta_{1} \mathrm{X}_{1}+\beta_{2} \mathrm{X}_{2}+\beta_{3} \mathrm{X}_{3}+\mathrm{e}
$$

$$
\begin{array}{ll}
\text { Keterangan: } \\
\mathrm{Y} \quad=\text { Penggunaan } e \text {-filing } \\
\alpha & =\text { Konstanta } \\
\beta_{1} & =\text { Koefisien regresi persepsi kebermanfaatan } \\
\beta_{2} & =\text { Koefisien regresi persepsi kemudahan } \\
\beta_{3} & =\text { Koefisien regresi persepsi efisien } \\
\mathrm{X}_{1} & =\text { Persepsi kebermanfaatan } \\
\mathrm{X}_{2} & =\text { Persepsi kemudahan } \\
\mathrm{X}_{3} & =\text { Persepsi efisien } \\
\mathrm{e} & =\text { Tingkat kesalahan atau tingkat gangguan }
\end{array}
$$

KPP Pratama Denpasar Timur digunakan sebagai lokasi penelitian karena beberapa alasan yaitu KPP Pratama Denpasar Timur bila dibandingkan dengan KPP Pratama Denpasar Barat, KPP Pratama Badung Selatan, dan KPP Pratama Badung Utara, KPP Pratama Denpasar Timur memiliki jumlah WPOP terbanyak ke-2 serta KPP Pratama Denpasar juga merupakan instansi vertikal, sehingga memiliki jumlah wajib pajak yang terdaftar cukup besar. Objek penelitian yaitu penggunaan e-filing bagi WPOP yang dipengaruhi oleh variabel persepsi kebermanfaatan, persepsi kemudahan, dan persepsi efisien di KPP Pratama Denpasar Timur yang terdaftar dan menggunakan serta mengisikan $e$-filing sendiri.

Persepsi kebermanfaatan $\left(\mathrm{X}_{1}\right)$, persepsi kemudahan $\left(\mathrm{X}_{2}\right)$, dan persepsi efisien $\left(\mathrm{X}_{3}\right)$ yang terdapat di penelitian ini adalah variabel independen sedangkan penggunaan $e$-filing (Y) adalah variabel dependen. Persepsi kebermanfaatan yaitu keyakinan individu bahwa dengan penggunaan suatu sistem informasi akan mampu memberikan keuntungan bagi mereka yang akan meningkatkan kinerjanya (Setyana \& Yushita, 2018). Persepsi kemudahan yaitu kepercayaan individu bahwa dengan menggunakan sistem dalam pekerjaan yang dimilikinya akan mempermudah dalam menyelesaikan suatu pekerjaan dan bebas dari usaha (Setyana \& Yushita, 2018). Persepsi efisien yaitu kepercayaan seseorang bahwa dalam melakukan pekerjaannya akan mengeluarkan biaya atau usaha yang lebih sedikit untuk mendapatkan manfaat yang lebih besar. Penggunaan $e$-filing adalah suatu penerapan dalam penggunaan program yaitu sistem pelayanan elektronik terhadap penyampaian SPT secara online dan realtime untuk pelaporan pajak. 
Jenis data dalam penelitian ini yaitu data kuantitatif dan kualitatif. Hasil pengukuran dari jawaban pernyataan yang terdapat dalam kuesioner yang telah disebarkan oleh peneliti merupakan data kuantitatif dan instrumen pernyataan pada kuesioner merupakan data kualitatif. Penelitian ini menggunakan sumber data primer yaitu jawaban WPOP yang terdaftar di KPP Pratama Denpasar Timur.

Seluruh WPOP yang terdaftar dan menggunakan serta mengisikan $e$-filing sendiri di KPP Pratama Denpasar Timur dalam penelitian ini adalah bagian dari populasi, sehingga populasi bersifat homogen. Data yang diberikan oleh KPP Pratama Denpasar Timur menyebutkan jumlah populasi dari WPOP pengguna $e$-filing pada tahun 2018 yaitu 24.754 orang. Penentuan jumlah sampel tergantung pada sifat populasi, semakin homogen populasi maka akan semakin kecil sampelnya dan sebaliknya. Penentuan sampel dapat dirumuskan dengan rumus Slovin dengan tingkat kesalahan $10 \%$ atau 0,1 , maka sampel yang diperlukan sebesar 99,59, angka tersebut dibulatkan ke 100. Metode nonprobability sampling yaitu incidental sampling merupakan cara untuk penentuan sampel.

Metode pengumpulan data dengan cara penyebaran kuesioner. Sebelum memberikan kuesioner kepada calon responden akan dilakukan wawancara terlebih dahulu untuk mendapatkan calon responden yang tepat dengan mewawancarai WPOP apakah sudah menggunakan serta mengisikan $e$-filing sendiri atau tidak, jika jawaban dari calon responden tersebut adalah tidak, maka calon responden tersebut tidak berhak menjadi sampel dalam penelitian ini. Kuesioner ini menggunakan likert scale 5 (lima) poin, yaitu: sangat tidak setuju (1), tidak setuju (2), cukup setuju (3), setuju (4), dan sangat setuju (5).

\section{Hasil dan Pembahasan}

Uji validitas digunakan untuk mengukur sah atau valid tidaknya suatu kuesioner (Ghozali, 2018). Suatu kuesioner dikatakan valid jika pertanyaan pada kuesioner mampu untuk mengungkapkan sesuatu yang akan diukur oleh kuesioner tersebut (Ghozali, 2018). Sampel berjumlah 100 responden, maka derajat kebebasan (df) adalah n-k atau 100-3 = 97 (n merupakan total responden dan k merupakan total variabel independen), sehingga $\mathrm{r}_{\text {tabel }}$ adalah 0,198. Hasil uji validitas dapat dilihat pada Tabel 3.

Tabel 3

Hasil Uji Validitas

\begin{tabular}{ccc}
\hline Variabel & Indikator & Koefisien Korelasi $\left(\mathbf{r}_{\text {hitung }}\right)$ \\
\hline Persepsi & $\mathrm{X}_{1.1}$ & 0,809 \\
Kebermanfaatan & $\mathrm{X}_{1} .2$ & 0,835 \\
$\left(\mathrm{X}_{1}\right)$ & $\mathrm{X}_{1} .3$ & 0,784 \\
& $\mathrm{X}_{1} .4$ & 0,729 \\
& $\mathrm{X}_{1} .5$ & 0,776 \\
& $\mathrm{X}_{1} .6$ & 0,825 \\
& $\mathrm{X}_{1} .7$ & 0,749 \\
& $\mathrm{X}_{1} .8$ & 0,739 \\
& $\mathrm{X}_{1} .9$ & 0,718 \\
\hline
\end{tabular}


Gede Mahaputra Chrisandita, I Made Sukartha

\begin{tabular}{ccc}
\hline Variabel & Indikator & Koefisien Korelasi $\left(\mathbf{r}_{\text {hitung }}\right)$ \\
\hline & $\mathrm{X}_{1} .10$ & 0,736 \\
\hline Persepsi Kemudahan & $\mathrm{X}_{2} .1$ & 0,856 \\
$\left(\mathrm{X}_{2}\right)$ & $\mathrm{X}_{2} .2$ & 0,806 \\
& $\mathrm{X}_{2} .3$ & 0,828 \\
& $\mathrm{X}_{2} .4$ & 0,876 \\
& $\mathrm{X}_{2} .5$ & 0,842 \\
& $\mathrm{X}_{2} .6$ & 0,879 \\
& $\mathrm{X}_{2} .7$ & 0,857 \\
Persepsi Efisien & $\mathrm{X}_{2 .} .8$ & 0,808 \\
$\left(\mathrm{X}_{3}\right)$ & $\mathrm{X}_{3} .1$ & 0,815 \\
& $\mathrm{X}_{3} .2$ & 0,851 \\
& $\mathrm{X}_{3} .3$ & 0,802 \\
& $\mathrm{X}_{3} .4$ & 0,801 \\
& $\mathrm{X}_{3} .5$ & 0,862 \\
Penggunaan & $\mathrm{X}_{3} .6$ & 0,740 \\
$e$-filing & $\mathrm{Y} .1$ & 0,790 \\
$(\mathrm{Y})$ & $\mathrm{Y} .2$ & 0,718 \\
& $\mathrm{Y} .3$ & 0,776 \\
& $\mathrm{Y} .4$ & 0,803 \\
& $\mathrm{Y} .5$ & 0,856 \\
& $\mathrm{Y} .6$ & 0,792 \\
\hline
\end{tabular}

Sumber: Data penelitian, 2020

Tabel 3 ritung setiap instrumen lebih besar dari 0,198, simpulannya adalah bahwa masing-masing instrumen adalah valid.

Uji reliabilitas digunakan untuk mengukur konsistensi dan stabilitas dari suatu kuesioner yang merupakan indikator dari variabel atau konstruk (Ghozali, 2018). Suatu kuesioner dikatakan reliabel atau handal jika jawaban seseorang terhadap pernyataan adalah konsisten atau stabil dari waktu ke waktu (Ghozali, 2018). Instrumen dikatakan reliabel jika memberikan nilai Cronbach's Alpha > 0,70 (Ghozali, 2018). Hasil uji reliabilitas dapat dilihat pada Tabel 4.

Tabel 4

Hasil Uji Reliabilitas

\begin{tabular}{lc}
\hline \multicolumn{1}{c}{ Variabel } & Cronbach's Alpha \\
\hline Persepsi Kebermanfaatan $\left(\mathrm{X}_{1}\right)$ & 0,920 \\
Persepsi Kemudahan $\left(\mathrm{X}_{2}\right)$ & 0,940 \\
Persepsi Efisien $\left(\mathrm{X}_{3}\right)$ & 0,896 \\
Penggunaan e-filing $(\mathrm{Y})$ & 0,871 \\
\hline
\end{tabular}

Sumber: Data penelitian, 2020

Tabel 4 menunjukkan nilai Cronbach's Alpha setiap variabel lebih besar dari 0,70, simpulannya adalah pernyataan di dalam kuesioner bisa dikatakan reliabel untuk digunakan dalam penelitian ini.

Uji asumsi klasik digunakan untuk memberikan kepastian bahwa persamaan regresi yang didapatkan memiliki ketepatan dalam estimasi tidak biasa dan konsisten (Gunawan, 
2018). Uji asumsi klasik meliputi uji normalitas, uji multikolinearitas, serta uji heteroskedastisitas.

Uji normalitas bertujuan untuk menguji apakah dalam model regresi, variabel pengganggu atau residual memiliki distribusi normal (Ghozali, 2018). Pengujian normalitas data dilakukan dengan uji kolmogorov-smirnov. Residual dikatakan berdistribusi normal apabila Asymp.Sig (2-tailed) lebih besar dari 0,05 (Ghozali, 2018). Hasil uji normalitas dapat dilihat pada Tabel 5.

Tabel 5

\begin{tabular}{cc}
\multicolumn{2}{c}{ Hasil Uji Normalitas } \\
\hline Keterangan & Unstandardized Residual \\
\hline N & 100 \\
Kolmogorov Smirnov $Z$ & 0,084 \\
Asymp.Sig (2-tailed) & 0,081 \\
\hline
\end{tabular}

Sumber: Data penelitian, 2020

Tabel 5 merupakan data yang sudah ditransformasi dengan menggunakan SPSS yaitu melakukan transformasi data seluruh variabel menjadi logaritma natural (Ln), hal ini dikarenakan data sebelum ditransformasi tidak berdistribusi normal. Tabel 5 memperlihatkan nilai Asymp.Sig (2-tailed) sebesar 0,081 yaitu berdistribusi normal.

Uji multikolinieritas bertujuan untuk menguji apakah pada model regresi ditemukan adanya korelasi antar variabel independen (Ghozali, 2018). Nilai yang umum digunakan untuk memperlihatkan adanya multikolinearitas adalah jika nilai tolerance $\leq 0,10$ atau nilai VIF $\geq 10$ (Ghozali, 2018). Hasil uji multikolinieritas dapat dilihat pada Tabel 6 .

Tabel 6

Hasil Uji Multikolinieritas

\begin{tabular}{ccc}
\hline Variabel & Tolerance & VIF \\
\hline Persepsi Kebermanfaatan $\left(\mathrm{X}_{1}\right)$ & 0,460 & 2,176 \\
Persepsi Kemudahan $\left(\mathrm{X}_{2}\right)$ & 0,464 & 2,157 \\
Persepsi Efisien $\left(\mathrm{X}_{3}\right)$ & 0,456 & 2,192 \\
\hline
\end{tabular}

Sumber: Data penelitian, 2020

Tabel 6 memperlihatkan nilai tolerance setiap variabel independen di atas 0,10 dan nilai VIF dibawah 10, simpulannya adalah tidak terdapat multikolinearitas pada setiap variabel.

Uji heteroskedastisitas bertujuan untuk menguji apakah dalam model regresi terjadi ketidaksamaan varians dari residual satu pengamatan ke pengamatan yang lain (Utama, 2016). Tingkat signifikansi setiap variabel independen lebih besar dari 0,05 maka tidak terdapat heteroskedastisitas (Utama, 2016). Hasil uji heteroskedastisitas dapat dilihat pada Tabel 7. 
Tabel 7

Hasil Uji Heteroskedastisitas

\begin{tabular}{cc}
\hline Variabel & Sig. \\
\hline Persepsi Kebermanfaatan $\left(\mathrm{X}_{1}\right)$ & 0,686 \\
Persepsi Kemudahan $\left(\mathrm{X}_{2}\right)$ & 0,214 \\
Persepsi Efisien $\left(\mathrm{X}_{3}\right)$ & 0,293
\end{tabular}

Sumber: Data penelitian, 2020

Tabel 7 memperlihatkan setiap variabel mempunyai signifikansi lebih besar dari 0,05. Simpulannya adalah setiap variabel tidak terdapat heteroskedastisitas.

Tabel 8

Hasil Uji Regresi Linear Berganda

\begin{tabular}{ccccccc}
\hline & & \multicolumn{2}{c}{$\begin{array}{c}\text { Unstandardized } \\
\text { Coefficients }\end{array}$} & $\begin{array}{c}\text { Standardized } \\
\text { Coefficients }\end{array}$ & t & Sig. \\
\hline & Model & B & Std.Error & Beta & & \\
\hline 1 & (Constant) & 2,649 & 1,013 & & 2,616 & 0,010 \\
& Persepsi Kebermanfaatan $\left(\mathrm{X}_{1}\right)$ & 0,100 & 0,032 & 0,180 & 3,150 & 0,002 \\
& Persepsi Kemudahan $\left(\mathrm{X}_{2}\right)$ & 0,101 & 0,031 & 0,187 & 3,275 & 0,001 \\
& Persepsi Efisien $\left(\mathrm{X}_{3}\right)$ & 0,601 & 0,053 & 0,650 & 11,321 & 0,000 \\
\hline
\end{tabular}

Sumber: Data penelitian, 2020 berikut:

Persamaan regresi dari hasil analisis pada Tabel 8 dapat dirumuskan sebagai

$$
\begin{aligned}
& \mathrm{Y}=\alpha+\beta_{1} \mathrm{X}_{1}+\beta_{2} \mathrm{X}_{2}+\beta_{3} \mathrm{X}_{3}+\mathrm{e} \ldots \ldots \ldots \ldots \ldots \ldots \ldots \ldots \\
& =2,649+0,100 \mathrm{X}_{1}+0,101 \mathrm{X}_{2}+0,601 \mathrm{X}_{3}+\mathrm{e}
\end{aligned}
$$

Nilai $\alpha$ menunjukkan 2,649 artinya jika persepsi kebermanfaatan, persepsi kemudahan dan persepsi efisien sama dengan nol, maka penggunaan e-filing bernilai positif. Nilai $\beta_{1}$ menunjukkan 0,100 artinya jika nilai persepsi kebermanfaatan ditingkatkan, maka nilai dari minat penggunaan e-filing akan cenderung mengalami peningkatan. Hal ini menunjukkan bahwa jika persepsi kebermanfaatan meningkat, maka minat penggunaan $e$-filing akan meningkat pula. Nilai $\beta_{2}$ menunjukkan 0,101 artinya jika nilai persepsi kemudahan ditingkatkan, maka nilai dari minat penggunaan e-filing akan cenderung mengalami peningkatan. Hal ini menunjukkan bahwa jika persepsi kemudahan meningkat, maka minat penggunaan $e$-filing akan meningkat pula. Nilai $\beta_{3}$ menunjukkan 0,601 artinya jika nilai persepsi efisien ditingkatkan, maka nilai dari minat penggunaan e-filing akan cenderung mengalami peningkatan. Hal ini menunjukkan bahwa jika persepsi efisien meningkat, maka minat penggunaan $e$-filing akan meningkat pula.

Tabel 9

Hasil Uji Koefisien Deterimnasi $\left(\mathbf{R}^{2}\right)$

\begin{tabular}{ccccc}
\hline Model & $\boldsymbol{R}$ & $\boldsymbol{R}$ Square & $\begin{array}{c}\text { Adjusted } \boldsymbol{R} \\
\text { Square }\end{array}$ & $\begin{array}{c}\text { Std. Error of the } \\
\text { Estimate }\end{array}$ \\
\hline $\mathbf{1}$ & 0,925 & 0,856 & 0,851 & 0,975 \\
\hline \multicolumn{5}{c}{ Sumber: Data penelitian, 2020 }
\end{tabular}


Tabel 9 memperlihatkan nilai adjusted $R^{2}$ sebesar 0,851 , artinya 85,1 persen dipengaruhi oleh variabel persepsi kebermanfaatan, persepsi kemudahan, dan persepsi efisien dalam penggunaan $e$-filing dan 14,9 persen dipengaruhi variabel lain.

Tabel 10

Hasil Uji Kelayakan Model (Uji F)

\begin{tabular}{ccccccc}
\hline Model & & $\begin{array}{c}\text { Sum of } \\
\text { Squares }\end{array}$ & df & $\begin{array}{c}\text { Mean } \\
\text { Square }\end{array}$ & F & Sig. \\
\hline $\mathbf{1}$ & Regression & 541,611 & 3 & 180,537 & 189,728 & 0,000 \\
& Residual & 91,349 & 96 & 0,952 & & \\
& Total & 632,960 & 99 & & & \\
\hline
\end{tabular}

Sumber: Data penelitian, 2020

Tabel 10 memperlihatkan nilai $\mathrm{F}_{\text {hitung }}$ sebesar 189,728 melebihi nilai $\mathrm{F}_{\text {tabel }}$ sebesar 2,70 dengan sig. F sebesar 0,000 , maka model regresi linear berganda sebagai alat analisis layak untuk melakukan pengujian pengaruh variabel independen pada variabel dependen dalam penelitian ini.

Uji hipotesis memiliki tujuan melihat pengaruh dari setiap variabel independen secara parsial terhadap variabel dependen. Pengujian dilakukan dengan membandingkan $t_{\text {hitung }}$ dengan $t_{\text {tabel }}$ dari setiap variabel. Nilai $t_{\text {hitung }}$ persepsi kebermanfaatan $(3,150)$, persepsi kemudahan $(3,275)$, dan persepsi efisien $(11,321)$ lebih besar dari $t_{\text {tabel }}(1,985)$. Tabel 8 menunjukkan tingkat signifikansi variabel persepsi kebermanfaatan $(0,002)$, persepsi kemudahan $(0,001)$, dan persepsi efisien $(0,000)$ lebih kecil dari $\alpha=0,05$. Hal ini menunjukkan bahwa setiap variabel independen berpengaruh positif pada variabel dependen dan semua hipotesis diterima.

Hipotesis pertama $\left(\mathrm{H}_{1}\right)$ menyatakan persepsi kebermanfaatan berpengaruh positif pada penggunaan $e$-filing. Hasil penelitian ini dapat diartikan bahwa semakin WPOP mempersepsikan $e$-filing dapat meningkatkan manfaat, maka penggunaan $e$-filing oleh WPOP akan meningkat. Hasil ini mendukung TAM, TPB serta mendukung penelitian sebelumnya. (Noviandini, 2012), (Lie \& Sadjiarto, 2013), dan (Syaninditha \& Setiawan, 2017) memperoleh hasil pengaruh positif dari persepsi kebermanfaatan pada penggunaan e-filing.

Hipotesis kedua $\left(\mathrm{H}_{2}\right)$ menyatakan persepsi kemudahan berpengaruh positif pada penggunaan e-filing. Hasil penelitian ini dapat diartikan bahwa semakin WPOP mempersepsikan $e$-filing dapat meningkatkan kemudahan, maka penggunaan $e$-filing oleh WPOP akan meningkat. Hasil ini mendukung TAM, TPB serta mendukung penelitian sebelumnya (Dharma \& Noviari, 2016), (Syaninditha \& Setiawan, 2017), dan (Dewi \& Noviari, 2018) memperoleh hasil pengaruh positif dari persepsi kemudahan pada penggunaan $e$-filing.

Hipotesis ketiga $\left(\mathrm{H}_{3}\right)$ menyatakan persepsi efisien berpengaruh positif pada penggunaan e-filing. Hasil penelitian ini dapat diartikan bahwa semakin WPOP mempersepsikan $e$-filing dapat meningkatkan efisiensi, maka penggunaan $e$-filing oleh WPOP akan meningkat. Hasil ini mendukung TAM, TPB serta mendukung penelitian sebelumnya (Lingga, 2012), (Tamboto, 2013), dan (Febriani \& Andi, 2016) memperoleh 
hasil bahwa penerapan e-filing berpengaruh positif pada efisiensi pelaporan pajak penghasilan orang pribadi.

Implikasi teoritis penelitian ini memberikan kontribusi mengenai pengaruh persepsi kebermanfaatan, persepsi kemudahan, dan persepsi efisien pada penggunaan $e$-filing bagi WPOP di KPP Pratama Denpasar Timur. Hasil uji dalam penelitian ini menemukan bahwa ketiga hipotesis diterima. Hasil penelitian ini mendukung teori TAM yaitu faktor untuk memprediksi penerimaan pengguna. Penelitian ini mendukung TPB yaitu timbulnya niat perilaku membentuk perilaku untuk menggunakan suatu sistem aplikasi tertentu yaitu penggunaan $e$-filing. Implikasi praktis penelitian ini yaitu memberikan kontribusi positif untuk DJP dalam meningkatkan minat WPOP dalam penggunaan $e$ filing dengan mempertimbangkan persepsi kebermanfaatan, persepsi kemudahan, dan persepsi efisien.

\section{Kesimpulan}

Simpulan yang dapat ditarik berdasarkan hasil diatas adalah persepsi kebermanfaatan, persepsi kemudahan, dan persepsi efisien mempunyai pengaruh positif pada penggunaan e-filing, artinya semakin WPOP mempersepsikan e-filing dapat meningkatkan manfaat, peningkatan kemudahan, dan peningkatan efisiensi maka penggunaan $e$-filing oleh WPOP akan meningkat. Berdasarkan penelitian serta simpulan maka saran yang dapat peneliti sampaikan kepada KPP Pratama Denpasar Timur yaitu KPP dapat menyediakan tenaga ahli untuk menyelesaikan masalah mengenai penggunaan e-filing yang siap melayani wajib pajak baik secara online maupun offline. Angka 14,9 persen menunjukkan penggunaan $e$-filing dipengaruhi oleh faktor lain yang tidak terdapat dalam penelitian ini, maka penelitian selanjutnya sebaiknya memertimbangkan mengganti atau menambahkan variabel lain yang berkaitan dengan penggunaan $e$-filing, seperti persepsi kepuasan, persepsi keamanan dan kerahasiaan, dan persepsi efektivitas. 
Pengaruh Persepsi Kebermanfaatan, Persepsi Kemudahan, dan Persepsi Efisien Wajib pajak Orang Pribadi pada Penggunaan $e$-filing

\section{BIBLIOGRAFI}

Aziz, Saliza Abdul, Azuan, Mohd, \& Bani, Ahmad. (2017). Tax E-Lejar Service: Determinants of Behavioral Intention among Individual Taxpayers in Kuala Lumpur. International Conference on E-Commerce 2017, 90-98. Google Scholar

Chang, Chi Cheng, Yan, Chi Fang, \& Tseng, Ju Shih. (2012). Perceived convenience in an extended technology acceptance model : Mobile technology and English learning for college students. Australasian Journal of Educational Technology, 28(5), 809826. Google Scholar

Démuth, Andrej. (2013). Perception Theories. Kraków: Towarzystwo Słowaków w Polsce. Google Scholar

Dewi, Putu Dessy Kurnia, \& Noviari, Naniek. (2018). Faktor-Faktor yang Memengaruhi Intensitas Perilaku dalam Penggunaan E-Filing Pada Wajib pajak Orang Pribadi. E-Jurnal Akuntansi Universitas Udayana, 22(3), 2368-2397. https://doi.org/10.24843/EJA.2018.v22.i03.p27. Google Scholar

Dharma, I. Wayan Maha Hredaya, \& Noviari, Naniek. (2016). Faktor-Faktor yang Berpengaruh pada Intensitas Perilaku dalam Penggunaan E-Filing oleh wajib pajak Orang Pribadi. E-Journal Akuntansi Universitas Udayana, 17(2), 1342-1370. Google Scholar

Febriani, Leny, \& Andi. (2016). Penerapan E-Filling Terhadap Efisiensi Pelaporan Pajak Penghasilan Orang Pribadi Pada Kantor Pelayanan Pajak Pratama Serang. Jurnal Riset Akuntansi Terpadu, 9(2), 179-191. Google Scholar

Ghozali, Imam. (2018). Aplikasi analisis multivariate dengan program IBM SPSS 25. Semarang: Badan Penerbit Universitas Diponegoro. Google Scholar

Gunawan, Ce. (2018). Mahir Menguasai SPSS: (Mudah mengolah Data Dengan IBM SPSS Statistic 25). Yogyakarta: Deepublish. Google Scholar

Gupta, Gaurav, Zaidi, Syed K., Udo, Godwin J., \& Bagchi, Kallol K. (2015). The Effect of Espoused Culture on Acceptance of Online Tax Filing Services in an Emerging Economy. Advances in Business Research, 6(1), 14-31. Google Scholar

Lie, Ivana, \& Sadjiarto, Raden Arja. (2013). Faktor-faktor yang mempengaruhi minat perilaku wajib pajak untuk menggunakan e-filing. Tax \& Accounting Review, 3(2), 147. Google Scholar

Lingga, Ita Salsalina. (2012). Pengaruh Penerapan e-SPT PPN Terhadap Efisiensi Pengisian SPT Menurut Persepsi Wajib pajak: Survey Terhadap Pengusaha Kena Pajak Pada KPP Pratama “ X .” Jurnal Akuntansi, 4(1), 70-86. Google Scholar

Noviandini, Nurul Citra. (2012). Pengaruh Persepsi Kebermanfaatan,Persepsi Kemudahan Penggunaan,dan Kepuasan Wajib pajak Terhadap Penggunaan eFiling bagi Wajib pajak di Yogyakarta. Jurnal Nominal, Barometer Riset Akuntansi Dan Manajemen, 1(1), 15-22. https://doi.org/10.21831/nominal.v1i1.988. Google 


\section{Scholar}

Setyana, Adis. (2017). Pengaruh Minat, Persepsi Kebermanfaatan dan Kemudahan Penggunaan e-filing terhadap Kepatuhan Wajib pajak (Studi Kasus pada Wajib pajak Orang Pribadi Magelang). Yogyakarta: Universitas Negeri Yogyakarta. Google Scholar

Setyana, Adis, \& Yushita, Amanita Novi. (2018). Pengaruh Minat, Persepsi Kebermanfaatan dan Kemudahan Penggunaan e-filing terhadap Kepatuhan Wajib pajak (Studi Kasus pada Wajib pajak Orang Pribadi Magelang). Jurnal Profita, 6(1), 1-14. Google Scholar

Syaninditha, Sang Ayu Putu, \& Setiawan, Putu Ery. (2017). Pengaruh Persepsi Kegunaan, Persepsi Kemudahan, Faktor Sosial, Dan Kondisi Yang Memfasilitasi Terhadap Minat Penggunaan E-Filing. E-Jurnal Akuntansi Universitas Udayana, 21(1), 86-115. Google Scholar

Tallaha, Affiza Mohd, Shukor, Zaleha Abdul, \& Hassan, Norul Syuhada Abu. (2014). Factors Influencing E-Filing Usage Among Malaysian Taxpayers: Does Tax Knowledge Matters? Jurnal Pengurusan, 40, 91-102. https://doi.org/10.17576/pengurusan-2014-40-08. Google Scholar

Tamboto, Falerian R. .. (2013). Penerapan, Pengaruh Terhadap, e-spt PPN Pengisian, Efisiensi PPN, SPT Pengusaha, Ersepsi Pajak kena Pajak pada KPP Pratama Manado. Jurnal EMBA, 1(4), 2059-2068. Google Scholar

Utama, Made Suyana. (2016). Aplikasi Analisis Kuantitatif. Denpasar: CV. Sastra Utama. Google Scholar

Wahyuni, Resky. (2015). Pengaruh Persepsi Kegunaan, Kemudahan, Keamanan dan Kerahasiaan, dan Kecepatan terhadap Intensitas Perilaku dalam Penggunaan e-filing (Studi Pada Wajib pajak Orang Pribadi di Kantor Pelayanan Pajak Pratama Pekanbaru Senapelan). Jom FEKON, 2(1), 1-15. Google Scholar

\section{Copyright holder:}

Gede Mahaputra Chrisandita, I Made Sukartha (2021)

First publication right:

Syntax Literate: Jurnal Ilmiah Indonesia

This article is licensed under:

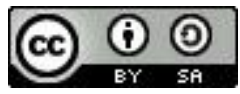

